$\begin{array}{llllllllll}\text { M } & \mathbb{A} & \mathrm{T} & \mathrm{E} & \mathrm{R} & \mathrm{I} & \overline{\mathrm{A}} & \mathrm{E} & \mathrm{Y}\end{array}$

Roman Jurkowski

Uniwersytet Warmińsko-Mazurski w Olsztynie

\title{
Czy każdy katolik to Polak? - kresowe, narodowo-religijne dylematy rosyjskiej biurokracji w dokumencie Ministerstwa Spraw Wewnętrznych z 1910 roku
}

Zarys treści: Przedstawiony tekst źródłowy jest dokumentem pokazującym bezradność carskiej biurokracji wobec skomplikowanych stosunków narodowościowo-wyznaniowych występujących w zachodnich guberniach Rosji, dawniej stanowiących ziemie Wielkiego Księstwa Litewskiego. Dążąc do tego, aby po powstaniu styczniowym skutecznie ograniczyć polskich ziemian w zakresie praw do władania majątkami ziemskimi, władze rosyjskie zmuszone były najpierw określić, kogo uznawały za „osobę polskiego pochodzenia” i jakie cechy wyróżniały takie osoby spośród innych właścicieli ziemskich. Referat zatytułowany: „Kogo należy uważać za «osobę polskiego pochodzenia»", przygotowany w 1910 r. przez naczelnika VII oddziału Departamentu Spraw Ogólnych Ministerstwa Spraw Wewnętrznych, jest świadectwem, że przez ponad pół wieku od upadku powstania władzom rosyjskim nie udało się precyzyjnie określić przedmiotu swoich działań represyjnych.

Outline of content: The presented historical source is a document revealing helplessness of the tsarist bureaucracy in face of complex national and denominational relations in the Western guberniyas of Russia which formerly belonged to the territory of the Grand Duchy of Lithuania. Trying to restrict the rights of Polish landowners to administer their landed properties after the fall of the January Uprising (1863), the tsarist authorities had to define "a person of Polish origin" and determine the features characteristic of such persons and distinguishing them from other landowners. A report titled "Who should be considered to be 'a person of Polish origin'?", prepared in 1910 by the head of the VII Section of the Department of General Matters of the Ministry of Internal Affairs, is a testimony to the fact that fifty years after the fall of the uprising the Russian authorities were unable to precisely determine their repressive actions.

Słowa kluczowe: ziemstwa zachodnie, Ministerstwo Spraw Wewnętrznych Rosji, definicja narodowości, polityka dyskryminacyjna Rosji

Keywords: Western zemstva, Ministry of Internal Affairs of Russia, definition of nationality, Russian policy of discrimination 
Gdy na ziemiach byłego Wielkiego Księstwa Litewskiego jeszcze trwało powstanie styczniowe, Michaił Murawjow i podlegające mu władze wojskowe i cywilne nie miały problemów z decyzją, kogo pociągnąć do odpowiedzialności za udział w powstaniu. Zarówno wszyscy „przestępcy polityczni”, czyli schwytani z bronią w ręku, jak i ci tylko podejrzewani o sprzyjanie powstaniu powinni być przykładnie ukarani, czy to karą śmierci, zsyłką, więzieniem, czy konfiskatą lub sekwestrem majątku. Ale Murawjowowi i popierającym go wysokim urzędnikom w Petersburgu nie chodziło o schwytanie i skazanie tylko tych, którzy rzeczywiście czynnie wystąpili przeciw Imperium Rosyjskiemu. Kary doraźne były jedynie początkiem całego systemu represji, który wprowadzono w guberniach zachodnich Rosji, a który pod pretekstem „ukarania miatieżników” miał realizować bardziej dalekosiężne cele. Chodziło bowiem o trwałą eliminację polskiego ziemiaństwa $\mathrm{z}$ życia politycznego, gospodarczego i społecznego ziem wschodnich dawnej Rzeczypospolitej. Ograniczenie roli gospodarczej i społecznej polskich ziemian miało stać się preludium do przyspieszonej rusyfikacji ludności litewskiej, białoruskiej i ukraińskiej, a co za tym idzie do jak najszybszego wchłonięcia tych ziem przez wielki organizm państwa Romanowów. Jednak zastosowanie odpowiedzialności zbiorowej za „bunt”, zwłaszcza gdy już dawno go stłumiono, wymagało precyzyjnego określenia, kto jest tym „buntownikiem”, czyli inaczej, aby zastosować długofalowe represje, należało najpierw stworzyć system prawny definiujący kogo represjonować. Taka była geneza powstania terminu „osoba polskiego pochodzenia”, który funkcjonował w prawniczo-urzędniczej terminologii administracji rosyjskiej od powstania styczniowego do końca istnienia caratu. Nawet w kilkadziesiąt lat po powstaniu styczniowym określenie to, użyte po raz pierwszy $\mathrm{w}$ akcie prawnym $\mathrm{w}$ marcu 1864 r., było wielokrotnie wykorzystywane do celów polityki narodowościowej Rosji w zachodnich guberniach Cesarstwa. Na kilka lat przed wybuchem I wojny światowej kwestia wyodrębnienia Polaków spośród ogółu ludności zamieszkującej dziewięć guberni zachodnich ponownie odżyła w związku z projektami wprowadzenia w sześciu z nich instytucji samorządu ziemskiego.

Problem objęcia w latach 1909-1911 guberni mińskiej, mohylewskiej, witebskiej, kijowskiej, podolskiej i wołyńskiej systemem ziemskim jest raczej dobrze opracowany w polskiej historiografii, przede wszystkim za przyczyną znakomitej biografii Piotra Stołypina napisanej przez Ludwika Bazylowa ${ }^{1}$. Zagadnienie to podjął także Paweł Wieczorkiewicz $\mathrm{w}$ obszernym artykule opublikowanym w księdze pamiątkowej poświęconej Bazylowowi². Dzięki bogatym materiałom zachowanym w Rosyjskim Państwowym Archiwum Historycznym w Petersburgu można obecnie z dużą precyzją przedstawić cały proces decyzyjno-przygotowawczy,

\footnotetext{
${ }^{1}$ L. Bazylow, Ostatnie lata Rosji carskiej. Rzady Stolypina, Warszawa 1972.

2 P. Wieczorkiewicz, Stołypin, Polacy i ziemstwa zachodnie, w: Słowiańszczyzna i dzieje powszechne. Studia ofiarowane Profesorowi Ludwikowi Bazylowowi w siedemdziesiąta rocznice Jego urodzin, Warszawa 1985, s. 125-153.
} 
który w związku z projektami ziemskimi dla tych guberni wykonano w rosyjskich instytucjach rządowych różnego szczebla, lecz na pełny opis całej skomplikowanej procedury potrzeba odrębnej monografii.

Zasadniczą kwestią, którą władze rosyjskie musiały podjąć przy wprowadzaniu ziemstw w wybranych guberniach zachodnich, było skonstruowanie takich zasad wyboru radnych, aby nie dopuścić do wybrania ziemian Polaków, którzy przy swojej większej liczebności w powiatach byliby także liczniejsi w ziemstwach niż radni narodowości rosyjskiej. Wymagało to diametralnego przekształcenia ordynacji wyborczej do ziemstw, w których to zmianach najistotniejsze było podzielenie wyborców według kryteriów narodowych. Po takim wyodrębnieniu wyborców, kolejnym krokiem było odpowiednie sfałszowanie statystyk, aby w połączeniu ze skomplikowanym systemem obliczeń liczby Polaków mających prawo wyboru radnych doprowadzić do „wykazania”, że polskich wyborców jest mniej niż rosyjskich. Tego nie było w pozostałych guberniach ziemskich, gdzie wybory oparte były na kuriach stanowych, nie narodowościowych ${ }^{3}$. Cała misterna i skomplikowana konstrukcja wyborów radnych do ziemstw przygotowana w Ministerstwie Spraw Wewnętrznych, mająca na celu sztuczną redukcję liczebności radnych polskiego pochodzenia, prowadziła do wypaczenia samej istoty ziemstwa jako miejscowego organu samorządowego. I dotyczyło to zarówno pierwotnego modelu ziemstwa z 1864 r., jak i mocno już ograniczonego z 1890 r. Fakt, że nowe ziemstwo nie miałoby wiele wspólnego $\mathrm{z}$ zasadami elekcji i pracy samorządu lokalnego, nie miał żadnego znaczenia dla urzędników MSW opracowujących sposoby „zmniejszenia” liczebności polskich ziemian w tych guberniach.

Premier Piotr Stołypin, inicjujący cały proces rozszerzenia organizacji ziemskiej na sześć guberni zachodnich ${ }^{4}$, obok zamiaru ograniczenia wpływu Polaków na działalność samorządu ziemskiego chciał jednocześnie zrealizować cel polityczny o zasięgu ogólnopaństwowym. Chodziło mu o to, aby doprowadzić do usunięcia Polaków z Ziem Zabranych z wybieralnej części Rady Państwa, gdyż w guberniach posiadających ziemstwa to one uczestniczyły w wyborze posłów do izby wyższej parlamentu rosyjskiego. Tym samym, po wprowadzeniu ziemstw przestawały funkcjonować tzw. zjazdy ziemian, dotąd działające w dziewięciu guberniach zachodnich pozbawionych ziemstw. W latach 1906, 1909 i 1910 na tych zjazdach, z powodu liczebnej przewagi Polaków, wybierano do Rady Państwa wyłącznie polskich ziemian.

Aby opracować cały skomplikowany system odrębnych obliczeń dla każdego powiatu w sześciu guberniach, w celu „udowodnienia”, że polskich ziemian jest tam mniej niż Rosjan, należało najpierw określić, kogo władze rosyjskie uważają za Polaków, co w zróżnicowanym narodowościowo i religijnie społeczeństwie

${ }^{3}$ Co było oczywiste, gdyż w guberniach rosyjskich dominowali ziemianie narodowości rosyjskiej.

${ }^{4}$ Już na samym początku prac nad ziemstwami zachodnimi w $1906 \mathrm{r}$. wykluczono z nich gubernie kowieńską, grodzieńską i wileńską, ponieważ liczba polskich ziemian była tam na tyle duża, że zafałszowanie statystyk musiałoby być szyte tak grubymi nićmi, iż przyniosłoby rządowi więcej szkód niż pożytku. 
żyjącym na ziemiach byłego Wielkiego Księstwa Litewskiego wcale nie było proste. Jeśli do tego dodać coraz silniej nabrzmiewające procesy narodowe wśród ludności litewskiej, ukraińskiej i białoruskiej, oraz „krajową” specyfikę poczucia narodowo-terytorialnego wśród części środowisk ziemiańskich - to, jak pokazuje przedstawiony dokument, zadanie okazało się dla administracji rosyjskiej problemem nie do rozwiązania.

Jedną z takich prób sprecyzowania, kogo należy uważać za „osobę polskiego pochodzenia", przygotowaną $\mathrm{w}$ związku z projektami wprowadzenia ziemstw w sześciu guberniach zachodnich, był referat Konstantego Strolmana, naczelnika VII oddziału Departamentu Spraw Ogólnych Ministerstwa Spraw Wewnętrznych ${ }^{5}$. Kierował on oddziałem, do kompetencji którego należały sprawy związane z polityką państwa wobec innych narodów zamieszkujących zachodnie kresy Imperium. Oddział VII zajmował się m.in. wzmocnieniem rosyjskiego stanu posiadania ziemi $\mathrm{w}$ dziewięciu guberniach zachodnich, przeciwdziałaniem rozpowszechnianiu języków ludności autochtonicznej, wszelkimi zagadnieniami związanymi ze „sprawą rosyjską" na ziemiach Kraju Zachodniego, problematyką ochrony granic państwa i stanu pogranicza ${ }^{6}$. $Z$ tych przyczyn opracowanie to znalazło się w bogatym objętościowo zbiorze dokumentów dostarczonych przez MSW do kancelarii Dumy Państwowej, w której rozpatrywano projekt rządowy, aby następnie, po zaakceptowaniu przez Dumę, posłać go do Rady Państwa7.

${ }^{5}$ Konstanty Aleksiejewicz Strolman (1861-1941) pochodził z rodziny o szwedzko-niemiecko-rosyjskich korzeniach. Po skończeniu Uniwersytetu Petersburskiego został 13 lutego 1891 r. zatrudniony w Departamencie Spraw Ogólnych Ministerstwa Spraw Wewnętrznych. Po reorganizacji Wydziałów Specjalnych w tym departamencie, od 1 stycznia 1903 r. jako urzędnik do specjalnych poleceń $\mathrm{V}$ klasy przy ministrze spraw wewnętrznych został wyznaczony od zorganizowania nowego, VII oddziału Departamentu Spraw Ogólnych, którym jako naczelnik kierował do 1917 r. Zmarł w Leningradzie podczas blokady. Był młodszym bratem Sergiusza Strolmana (1854-1937) generała korpusu inżynierów górnictwa, od 1897 r. dyrektora Permskich Zakładów Artyleryjskich.

${ }^{6}$ Rosyjskie Państwowe Archiwum Historyczne w Sankt Petersburgu (dalej: RGIA), f. 1284 (Департамент общих дел МВД), ор. 183, d. 34, k. 56. O szczególnej roli Departamentu Spraw Ogólnych MSW za czasów ministerstwa Dymitra Sipiagina i Wiaczesława Plehwe, zob. Н.Г. Базина, Возникновение национально-политической части Департамента общих дел Министерства внутренних дел, „Известия Российского государственного педагогического университета им. А.И. Герцена” (2006), вып. № 22, т. 4, s. 17-23.

7 Rada Państwa 4 marca 1911 r. odrzuciła projekt ziemstw zachodnich, co okazało się największą klęską polityczną P. Stołypina w jego karierze. Wprawdzie wymógł on na Mikołaju II wydanie dekretu o przerwaniu zajęć obu izb na trzy dni i 14 marca 1911 r., na mocy $\$ 87$ Ustaw Zasadniczych opublikowano ustawę ziemską dla sześciu guberni zachodnich, ale zgodnie z prawem dekret cesarski wydany w oparciu o $\$ 87$ powinien być następnie uprawomocniony przez Dumę Państwową i Radę Państwa. A tego nigdy nie dokonano - więc wybory do Rady Państwa w 1913 r. powinny być, jeśli trzymać się litery prawa, zorganizowane w oparciu o poprzednią ordynację. Tak się jednak nie stało, gdyż minister spraw wewnętrznych Mikołaj Makłakow przeszedł do porządku dziennego na kwestiami prawnymi i zarządził przeprowadzenie wyborów w sześciu guberniach przez tzw. stołypinowskie zgromadzenia ziemskie powstałe w oparciu o dekret z 14 marca $1911 \mathrm{r}$. Nie wybrano tam ani jednego Polaka do Rady Państwa. 
Prezentowany dokument, zachowany w zbiorach Rosyjskiego Państwowego Archiwum Historycznego w Sankt Petersburgu, ma charakter analizy historyczno-prawnej. Jego treść jest nierozerwalnie związana z systemem represji po powstaniu styczniowym zastosowanym wobec polskiego ziemiaństwa. To wówczas pojawił się termin „osoba polskiego pochodzenia”, potrzebny władzom do podzielenia posiadaczy ziemskich na Polaków i nie-Polaków w warunkach funkcjonowania praw ograniczających polskie ziemiaństwo w dysponowaniu własnymi majątkami. Jak widać $\mathrm{z}$ dokumentu, pojęcie to do $1910 \mathrm{r}$., jak i do końca istnienia caratu, nigdy nie zostało sprecyzowane ani prawnie zdefiniowane. W praktyce oznaczało to oddanie w ręce generałów-gubernatorów i gubernatorów prawa do decydowania, kto jest, a kto nie jest „osobą polskiego pochodzenia”. Dokument jest świadectwem nie tylko ogromnych trudności terminologiczno-prawnych, przed którymi stał rosyjski aparat urzędniczy na ziemiach litewsko-białorusko-ukraińskich. Pokazuje też, jak złożone były (i są nadal!) problemy dotyczące określenia wyznaczników charakteryzujących przynależność narodową (zwłaszcza w realiach kresowych końca XIX i początku XX w.) i jak wymykają się próbom ich ułożenia, usystematyzowania i logicznego zdefiniowania.

Kilkustronicowy maszynopis formatu A4 został dostosowany do współczesnej pisowni rosyjskiej, przetłumaczony przez autora i zaopatrzony w aparat przypisów ${ }^{8}$.

\section{Доклад начальника VII отделения Департамента общих дел Министерства внутренних дел, статского советника Строльмана по вопросу о том кого следует считать „лицом польского происхождения".}

РГИА, Ф. 1278 (Канцелярия Государственной Думы) оп. 2, д. 1171 (Об применении положения о земских учреждениях 12 июня 1890 г. к губерниям: Витебской, Волынской, Киевской, Минской, Могилевской и Подольской, 22 I 1910 - 14 III 1911 г.), л. 101-103.

Прежде всего считаю долгом доложить, что в Министерстве внутренних дел не имеется по этому богатых данных. Причиной этого недостатка является то обстоятельство, что ограничительные узаконения касающихся лиц польского происхождения применялись на практике местными властями, которым и приходилось останавливаться на обсуждении настоящего вопроса. Правда, в Министерстве внутренних дел нередко поступали жалобы лиц этой категории на местные власти за применение к ним ограничительных узаконений, но и в этом случае министерству не предоставлялось надобности задумываться над вопросом, что разумеется в понятии „лица польского происхождения”.

8 Wyrażam podziękowanie Pani prof. dr hab. Iwonie Annie Ndiaye za korektę językową i cenne uwagi dotyczące zarówno oryginału, jak i tłumaczenia zamieszczonego dokumentu. 
Так все этого рода узаконения оперались на дискреционную, по объяснению Правительствующего сената, власти генерал-губернаторов и министерству достаточно было не входя в обсуждение дела по существу, доносить правительствующему сенату, что обжалованное распоряжение последовало в пределах дискреционной власти местного начальства и не подлежит рассмотрению Правительствующего сената по существу.

Понятие „лица польского происхождения” есть термин ограничительного законодательства в области национально-политической. Впервые, насколько мне известно, он встречается в Высочайше утвержденном 5 марта 1864 г. Положении о льготах, преимуществах и денежных ссудах предоставляемых при покупке казенных и частных имений в западных губерниях. В ст. 26 этого положения значится: „всем приобретателям имений воспользовавшимся каким-либо из установленных настоящим положением льготами и преимуществами или пособием равно их наследниками и преемниками прав запрещается продавать, закладывать или иным образом передавать те имения лицам польского происхождения и евреям". Такого же рода статья содержится и в Высочайше утвержденной 23 июля 1865 г. Инструкции о порядке продажи казенных земель в западных губерниях лицам русского происхождения [wyróżnienie oryg. - R.J.] служащим в том крае или желающих там водворится на постоянное жительство. Далее тот же термин содержится в Высочайшем повелении 10 декабря 1865 года, коим воспрещено приобретение лицам польского происхождения имений в Западном крае всяким иным путем кроме наследования по закону. В Высочайше утвержденном в тот же день (т.е. 10 декабря 1865 г.) журнале особой комиссии под председательством Д.Т.С. [действительный тайный советник] князя Гагарина, о мерах к водворению в Западном крае русского элемента, на основании какого журнала и последовал приведенное выше Высочайшее повеление 10 декабря 1865 г. содержится попытка дать общее указания относительно термина „лица польского происхождения”. Под выражением „лица польского происхождения", говорится здесь, нужно понимать, не вообще католиков а только поляков и тех западных уроженцев [wyróżnienie oryg. - R.J.], которые усвоили себе польскую национальность. Хотя в юридическом отношении выражение это может указаться неточным, но на практике к применении к лицам оно не возбуждало доселе никаких сомнений. Между тем, выражением этим устраняется вполне вопрос о вероисповедании, так как было бы совершенно несправедливо делать различие между владельцами не по политическим, а по религиозным соображениям.

Затем известна попытка министра Государственных имуществ дать определение понятию „лица польского происхождения”. Именно в отзыве к генерал-губернатору Северо-Западного края от 10 декабря 1869 г. за № 22, названный министр сообщил: „В виду изложенного в Высочайше утвержденном 10 декабря 1865 г. журнале коммисии, столь ясного указания на то, 
что основанием к установлению различия между лицами польского происхождения, коим воспрещено приобретение имений в Западном крае и лицам непольского происхождения, должна служить национальность, а не вероисповедание этих лиц, он, министр Государственных имуществ находит что принятие лицом польского происхождения православной веры не может служить законным поводом к изятию его из действия закона 10 декабря 1865 г. Если потомки этих лиц, будучи православного исповедания усвоят себе, со временем, русскую национальность, точно также как предки многих нынешних польских помещиков Западного края, бывшие некогда русскими, усвоили себе постепенно польскую национальность после перехода из православия в латинство, то все же, для действительного достижения этой перемены национальности нужно немало времени по прошествии коего лица, эти будучи русскими на самом деле, и окончательно отрешившись от польского языка, перестанут считаться лицами польского происхождения. Но действительная перемена национальности не может быть непосредственным, мгновенним последствием перемены исповедания , а потому, если бы допустить изъятие из постановленных относительного лиц польского происхождения правил в пользу всех тех из числа лиц этих кои приняли православие, то это прямо значило бы установить различие между лицами польского и не польского происхождения, но не по национальности а по вероисповеданию, что было бы совершенно противно духу и буквальному смыслу закона 10 декабря 1865 г. , который должен всемирно охраняться от всякого его изменения или ослабления.

В виду сего лица польского происхождения хотя и бы принявшие православие ни в каком случае не могут приобретать казенную поземельную собственность на основании Инструкции 23 июля 1865 г. так как собственность эта „продается для привлечения чиновников русского происхождения на службу в западные губерни и для пощрения их к продолжению там службы, а также в видах содействия другим благонадежным лицам русского же происхождения к постоянному в том крае водворению”. В дальнейшем вопроса этого не приходилось касаться до 1905 г. Тем более что 1 ноября 1886 г. было издано Высочайше утвержденное Положение Комитета Министров, которые предоставило дискреционному усмотрению местных начальств выдавать или не выдавать свидетельства на право приобретения имений в Западном крае „как лицам русского, так и нерусского происхождения”.

Далее, на разъяснении этого-же понятия пришлось остановиться и Комитету Министров, когда последний производил пересмотр действующих постановлений ограничивающих права инородцев и уроженцев отдельных местностей Империи в исполнение пункта 7 Именного Высочайшего Указа 12 декабря 1904 г. о предначертаниях к усовершенствованию государственного порядка, коим повелевалось произвести пересмотр этих постановлений, с тем, чтобы из числа их вперед сохранены были лиш те, которые 
называются насущными интересами государства и явною пользою русского народа. Именно в Высочайше утвержденном 1 мая 1905 г. особом журнале Комитета Министров по делу о порядке выполнения пункта 7 помянутого указа читаем: „Остановление на вопросе, кому может быть предоставлено удостоверять это обстоятельство т.е. принадлежность к лицам польского происхождения, Комитет находит что за неустановлением в законе точных признаков понятия «польское происхождение», поручить сию обязанность совершающим купчие крепости нотариусам было бы затруднительно. Одни лиш чины местной высшей администрации в лицах генерал-губернатора и губернатора могут решать подобные дела в сущестности характера не юридического а политического и тем более сложные, что среди католиков могут быть также и лица не польского происхождения, которых не следует стеснять в покупке имений. Лишь в их распоряжении имеются средства убедиться в том, не является ли проситель поляком или ополяченым литовцем, которого в сем отношении следует приравнивать к полякам. За названными высшими местными начальствами по прежнему надлежит сохранить также право предъявления в суда исков об уничтожении актов состоявшихся по незаконной сделке”.

Высочайшее повеление 1 мая 1905 г. отменило вышеприведенное законоположение 1 ноября 1886 г. и ныне местным начальствам уже не принадлежит дискреционное право выдачи или не выдачи свидетельств на право приобретения имений в Западном крае. В следствие сего поступившую ныне жалобу на распоряжение одного из местных губернских начальников о признании данного лица лицом польского происхождения препровожденную Правительствующим сенатом на заключение Министерства, подлежит рассмотреть по существу. В этих видах Министерство обратилось к генерал-губернаторам и губернаторам Западного края прося их сообщить, с точки зрения наблюдателя местной окраинной жизни, кого следует относить к числу лиц польского происхождения. Все отзывы доставлены, но к сожалению их невозможно было дать в настоящую минуту, так как они находятся в Министерстве Финансов, куда они препровождены в виду поручения Правительствующего Сената представить ему заключение по означенной жалобе, по сношении с Министерством Финансов (дело касалось залога имении в Дворянском банке). Следует однако заметить что и эти отзывы не дают ясного, точного и исчерпывающего определения рассматриваемого понятия. Некоторые отзывы отожествляют польское происхождение с принадлежностю к римско-католической церкви: по этому определению всякий католик есть польяк.

Затем можно привести следующую попытку одного из местных начальников обяснить предлежащий вопрос: „Лицом польского происхождения считается тот, кто родился от польских родителей и сам католик. Принятие им или его родителями православие не изменяет его польской национальности. Лишь происхождение просителя исповедующего православную веру от 
родителей, рожденных в православию может считаться достаточным основанием к признанию просителья лицом непольского происхождения".

Обращаясь со своей стороны к рассмотрению настоящего вопроса я лично пологаю, что отождествлять польское происхождение с принадлежностю к римской церкви едва-ли правильно. Во первых, в Западном крае есть обширная группа католического населения, которая не только не считает себя поляками, но находится с ними в антагонизме. Это литовско-жмудская народность, населяющая ковенскую губернию, численностю приблизительно около 1,5 миллионов. Литовцы с того времени, как среди них с особой силой начало появляться национальное самосознание, именно с середины 80-х годов настолько обесобились от поляков что стали требовать совершения у себя дополнительного богослужения не по польски а по литовски. На этой почве между литовцами а поляками происходили кровавые столкновения в костелах.

Против определения польского происхождения по признаку принадлежности к римской церкви, говорит и то соображение, что среди польяков имеется немало лютеран, а есть даже и православные. Так в 1902 г. Министерство в рапорте в Сенат признало лицом польского происхождения одного православного принесшего жалобу на отнесение его к числу лиц польского происхождения. Кроме того можно указать на наличность у нас общественных и государственных деятелей, которых нельзя не признать лицами русского происхождения несмотря на исповедывание ними католической религии. Я позволю себе привести один пример. Некто имя которого я потом назову. Родился в Вилне в католической семе и сам католик. Воспитывался в Виленской гимназии. После переехал в Петербург, поступил в одну из высших училищ, после в одну из академий. Кончил курс и был при ней профессором. Преподавал фортификацию Его Императорскому Величеству Государию Императору. Второй его специальностю была музыка, к которой у него имеется большой талант, при чем в течение свыше 40 лет он был музыкальным критиком, с фанатизмом отстаивая так называемую русскую музыку, перед коей он преклонялся и сам творил в духе новой русской школы. Вся жизнь его прошла в тесном общении с такими в полном смысле русским людми как покойный В. В. Стасов, трибун русского исскуства, русской старины Н. А. Римский-Корсаков, перелагавший на музыку наши былины, нашу мифологию Бородин, творец князя Игоря, Мусоргский, Балакирев. Я говорю об инжинере-генерале Ц. А. Кюи, которого иначе как русским общественным, государственным деятелем нельзя назвать.

По моему мнению польскую национальность следует определять по признаку употребления в домашнем быту польского языка. Затем не отрицая действительной связи между католиками и полонизмом в западном крае, я думал бы, что поляком следует считать того кто употребляет в домашнем быту польский язык и при этом исповедует римско-католическую веру. 
Конечно и это определение нельзя признать вполне исчерпывающим свой предмет - исключение, конечно, возможно.

\section{Referat naczelnika VII wydziału Departamentu Spraw Ogólnych Ministerstwa Spraw Wewnętrznych, radcy państwowego Strolmana w sprawie, kogo należy uważać za „osobę polskiego pochodzenia”.}

Rosyjskie Państwowe Archiwum Historyczne w Sankt Petersburgu, zespół 1278 (Kancelaria Dumy Państwowej), inw. 2, j.a. 1171 (O zastosowaniu przepisów o instytucjach ziemskich z 12 czerwca 1890 r. w guberniach: witebskiej, wołyńskiej, kijowskiej, mińskiej, mohylewskiej i podolskiej, 22 I 1910 - 14 III 1911 r.), k. 101-103.

Przede wszystkim uważam, że moim obowiązkiem jest poinformować, że w Ministerstwie Spraw Wewnętrznych brak bogatych danych $\mathrm{w}$ tej sprawie. Przyczyną tego niedoboru jest ta okoliczność, że prawa ograniczające dotyczące osób polskiego pochodzenia były stosowane w praktyce przez władze lokalne, które same musiały podejmować decyzje w tych kwestiach. Wprawdzie do Ministerstwa Spraw Wewnętrznych często napływały skargi od osób tej kategorii na władze miejscowe za stosowanie wobec nich praw ograniczających, ale i w takim przypadku w ministerstwie nie odczuwano potrzeby zastanawiania się nad kwestią, co należy rozumieć pod pojęciem „osoby polskiego pochodzenia”. Tak więc wszystkie tego rodzaju przepisy prawa opierały się na uznaniowej, według wyjaśnień Senatu Rządzącego ${ }^{9}$, decyzji generałów-gubernatorów i ministerstwu wystarczało to, aby nie wchodząc w omówienie istoty sprawy, donosić Senatowi Rządzącemu, że zaskarżone rozporządzenie wydane zostało przez władze miejscowe w oparciu o posiadane przez nie prawo decyzji uznaniowej i z tego powodu merytorycznie nie podlega rozpatrzeniu przez Senat Rządzący.

Pojęcie „osoba polskiego pochodzenia” stanowi termin z zakresu praw ograniczających i dotyczy dziedziny narodowo-politycznej. Po raz pierwszy, o ile mi wiadomo, został odnotowany w zatwierdzonym przez Cesarza 5 marca $1864 \mathrm{r}$. rozporządzeniu o ulgach, korzyściach i kredytach pieniężnych udzielanych przy zakupie majątków skarbowych i prywatnych w guberniach zachodnich ${ }^{10}$. W art. 26 tego rozporządzenia zaznaczono: „wszystkim nabywcom majątków korzystającym

9 Senat Rządzący powstał 19 lutego 1711 r. jako wyższa instytucja państwowa zajmująca się działalnością centralnych organów administracji i regulacjami prawnymi. W epoce Piotra I był podporządkowany wyłącznie cesarzowi. Od początku XIX w. do $1864 \mathrm{r}$. wypełniał funkcje kontrolne nad najwyższymi instytucjami władzy państwowej. Po roku 1864 do 1917 był najwyższą instancją kasacyjną w Imperium Rosyjskim.

10 Полное собрание законов Российской Империи (dalej: ПСЗ), Собрание 2, т. XXXIX (1864), № $40655,40656$. 
z jakichkolwiek ulg i korzyści lub środków określonych w niniejszym rozporządzeniu, jak też spadkobiercom ich uprawnień i następcom, zabrania się sprzedawać, zastawiać lub inaczej przekazywać te posiadłości osobom polskiego pochodzenia i Żydom". Ten sam rodzaju artykułu zawarty jest w zatwierdzonej przez Cesarza 23 lipca 1865 r. Instrukcji o zasadach sprzedaży ziem skarbowych w guberniach zachodnich osobom rosyjskiego pochodzenia [wyróżnienie oryg. - R.J.] pracującym w tym kraju, lub pragnących się tam na stałe osiedlić ${ }^{11}$. Następnie termin ten zawarty jest w Cesarskim dekrecie z 10 grudnia 1865 r., który zakazuje osobom polskiego pochodzenia nabywania majątków w Kraju Zachodnim każdą inną drogą poza dziedziczną sukcesją ${ }^{12}$. W zatwierdzonym przez Cesarza tego samego dnia (tj. 10 grudnia 1865 r.) dzienniku obrad specjalnej komisji pod przewodnictwem rzeczywistego tajnego radcy księcia [Pawła] Gagarina powołanej do sprawy określenia środków w celu osiedlenia w kraju Zachodnim elementu rosyjskiego, na podstawie którego to dziennika obrad nastąpiło wspomniane wyżej wydanie dekretu z 10 grudnia 1865 r., zawarta jest próba podania ogólnych wytycznych dotyczących terminu „osoby polskiego pochodzenia”. Powiedziane jest tam, że pod wyrażeniem „osoby polskiego pochodzenia” należy rozumieć nie ogół katolików, a tylko Polaków i tych rodzimych [wyróżnienie oryg. - R.J.] mieszkańców ziem zachodnich, którzy przyswoili sobie polską narodowość" ${ }^{13}$. Jakkolwiek $\mathrm{w}$ sensie prawnym wyrażenie to może wydawać się nieprecyzyjnym, ale w praktyce, w odniesieniu do osób, nie wywoływało do tej pory żadnych wątpliwości. Między innymi, określenie to w pełni eliminowało problem wyznania, ponieważ byłoby to całkiem niesprawiedliwe dokonać rozróżnienia między właścicielami z powodów religijnych, a nie politycznych.

Znana jest też próba ministra dóbr państwowych zdefiniowania pojęcia „osoby polskiego pochodzenia”. Mianowicie w wyjaśnieniu ( $\mathrm{nr} 22$ ) skierowanym w dniu 10 grudnia 1869 r. do generała-gubernatora Kraju Północno-Zachodniego, wymieniony minister poinformował: „Wobec zawartego w zatwierdzonym przez Cesarza 10 grudnia 1865 r. dzienniku obrad komisji, tak wyraźnego wskazania na to, że podstawą do określenia różnicy między osobami polskiego pochodzenia, którym zabroniono nabywania majątków w Kraju Zachodnim, a osobami niepolskiego pochodzenia, powinna być narodowość, a nie wyznanie tych osób, on, minister dóbr państwowych uważa, że przyjęcie wiary prawosławnej przez osobę polskiego pochodzenia nie może być prawną przyczyną do niezastosowania wobec niego przepisów z 10 grudnia 1865 r. Jeśli potomkowie tych osób, będących wyznania prawosławnego, z czasem przyswoją sobie narodowość rosyjską, dokładnie tak jak przodkowie wielu dzisiejszych polskich ziemian Kraju Zachodniego, którzy

11 ПСЗ, Собрание 2, т. XL (1865), № 41 957; т. XLII (1867), № 42328.

12 ПСЗ, Собрание 2, т. XL (1865), ч. 2, № $42759,42760$.

13 RGIA, f. 1263 (Комитет Министров), ор. 4, d. 6, Журнал особой коммисси Высочайше утвержденной для рассмотрения Всеподданнейшаго доклада Министра государственных имуществ о мерах к водворению русского элемента в Западном крае. 
kiedyś byli Rosjanami, stopniowo przyswoili sobie polską narodowość po przejściu z prawosławia do katolicyzmu, to mimo wszystko dla rzeczywistego osiągnięcia tej zmiany narodowości potrzeba niemało czasu, po upłynięciu którego osoby te będą Rosjanami w samej istocie i ostatecznie odżegnując się od języka polskiego przestaną być uważane za osoby polskiego pochodzenia. Ale rzeczywista zmiana narodowości nie może być natychmiastową, bezpośrednią konsekwencją zmiany wyznania i dlatego, jeśliby dopuścić do wyłączenia $\mathrm{z}$ obowiązujących przepisów dotyczących osób polskiego pochodzenia, wszystkich tych, którzy przyjęli prawosławie, to po prostu znaczyłoby, że tworzymy różnicę między osobami polskiego i niepolskiego pochodzenia, ale nie według narodowości, a według wyznania, co byłoby całkowicie sprzeczne $\mathrm{z}$ duchem i dosłownym rozumieniem dekretu z 10 grudnia 1865 r., który powinien być w całości chroniony od wszelkich zmian i osłabiania jego siły".

W związku z powyższym, osoby polskiego pochodzenia chociażby i przyjęły prawosławie w każdym przypadku nie mogą nabywać skarbowych posiadłości ziemskich w oparciu o Instrukcję z 23 lipca 1865 r., jako że nieruchomości te „sprzedawane są dla przyciągnięcia urzędników rosyjskiego pochodzenia na służbę w guberniach zachodnich i dla zachęcenia ich do kontynuowania tam pracy, a także w celu wspomożenia innych prawomyślnych osób rosyjskiego pochodzenia w stałym osiedleniu się w tym kraju". W następnych latach kwestia ta nie była podnoszona do $1905 \mathrm{r}$. Tym bardziej, że 1 listopada $1886 \mathrm{r}$. wydano zatwierdzone przez Cesarza poufne rozporządzenie Komitetu Ministrów, które pozostawiało do uznania władz miejscowych wydawanie lub niewydawanie świadectw pozwalających nabywać majątki w Kraju Zachodnim przez „osoby rosyjskiego, jak i nierosyjskiego pochodzenia" 14 .

Następnie, wyjaśnieniem tego pojęcia zajął się Komitet Ministrów, gdy tenże dokonywał przeglądu obowiązujących przepisów dotyczących ograniczeń praw innych narodowości i mieszkańców niektórych obszarów Imperium, w celu zrealizowania 7 punktu Imiennego dekretu cesarskiego z 12 grudnia 1904 r. o środkach na rzecz poprawy porządku państwowego ${ }^{15}$, w którym polecono dokonanie

${ }^{14}$ ПСЗ, Собрание 3, т. VI (1886), № 3895.

15 Punkt 7 brzmiał: „Произвести пересмотр действующих постановлений, ограничивающих право инородцев и уроженцев отдельных местностей Империи, с тем, чтобы из числа сих постановлений впредь сохранены были лишь те, которые вызываются насущными интересами Государства и явною пользою Русского Народа” („Dokonać przeglądu obowiązujących przepisów ograniczających prawa innych narodów i ludności miejscowej w różnych częściach Imperium, z tym aby $\mathrm{z}$ liczby tych przepisów zachowane zostały najpierw te, które chronią żywotne interesy państwa i są korzystne dla narodu rosyjskiego") (Законодательные акты переходного времени. 1904-1908 гг. Сборник законов, манифестов, указов Пр. Сенату, рескриптов и положений комитета министров, относящихся к преобразованию государственного строя России, с приложением алфавитного предметного указателя, изд. 3-е, пересм. и доп. по 1 сентября 1908 года, ред. Н.И. Лазаревский, Санкт-Петербург 1909, s. 3-6). 
przeglądu takich przepisów, $\mathrm{z}$ tym zastrzeżeniem, żeby $\mathrm{z}$ ich liczby były zachowane przede wszystkim te, które chronią żywotne interesy państwa i są korzystne dla narodu rosyjskiego. W zatwierdzonym przez Cesarza 1 maja 1905 r. dzienniku obrad Komitetu Ministrów dotyczącego trybu realizacji punktu 7 wspomnianego dekretu, czytamy: „Zatrzymując się na kwestii, komu może być przyznane to poświadczenie, tj. dotyczące przynależności do osób polskiego pochodzenia, Komitet uważa, że $\mathrm{z}$ powodu nieokreślenia $\mathrm{w}$ prawie dokładnych cech pojęcia «polskie pochodzenie», byłoby trudno powierzyć ten obowiązek notariuszom sporządzającym akty kupna majątków. Wyłącznie urzędnicy miejscowej wyższej administracji w osobach generała-gubernatora i gubernatorów mogą rozstrzygać podobne kwestie, opierając się na istocie ich politycznego, a nie prawniczego charakteru i tym bardziej złożone, że wśród katolików mogą być także osoby niepolskiego pochodzenia, których nie należy ograniczać w zakupie majątków. Tylko w ich dyspozycji są środki upewnienia się w tym czy proszący nie jest Polakiem lub spolonizowanym Litwinem, którego w tym zakresie należy utożsamiać z Polakami. Wymienionym wyżej miejscowym wyższym władzom, jak wcześniej, tak i teraz należy pozostawić prawo do wniesienia do sądów skarg dotyczących unieważnienia aktów opartych na nielegalnych transakcjach"16.

Dekret cesarski z 1 maja $1905 \mathrm{r}$. anulował wyżej przytoczony przepis prawny z 1 listopada 1886 r. i obecnie wyższym władzom terenowym już nie przysługuje uznaniowe prawo do wydawania lub niewydawania pozwoleń na nabywanie majątków w Kraju Zachodnim ${ }^{17}$. W następstwie tego skarga, na rozporządzenie jednego $\mathrm{z}$ gubernatorów uznająca daną osobę za osobę polskiego pochodzenia, która wpłynęła obecnie do Senatu Rządzącego z polecenia ministerstwa [prawdopodobnie MSW - R.J.] zostanie rozpatrzona według kryteriów merytorycznych. W tego rodzaju sprawach ministerstwo [prawdopodobnie MSW - R.J.] zwróciło się do generałów-gubernatorów i gubernatorów Kraju Zachodniego, prosząc ich o informację, z punktu widzenia obserwatorów życia kresowego, kogo powinno się zaliczać do osób polskiego pochodzenia. Wszystkie opinie zostały dostarczone, ale niestety nie było możliwości przytoczyć ich w tej chwili, jako że znajdują się one w Ministerstwie Finansów, dokąd zostały przekazane w myśl polecenia Senatu Rządzącego, aby przedstawić mu opinię Ministerstwa Finansów w sprawie rzeczonej skargi (sprawa dotyczyła kaucji za nieruchomość w Banku Szlacheckim). Należy jednak zauważyć, że także i te odpowiedzi nie dają jasnej, dokładnej i wyczerpującej definicji analizowanego pojęcia. Niektóre opinie identyfikują polskie pochodzenie z przynależnością do kościoła rzymsko-katolickiego: zgodnie z tym określeniem każdy katolik jest Polakiem.

16 Извлечения из Высочайше утвержденного 1 мая 1905 года особого журнала комитета министров 15, 22 и 23 марта 1905 г. по делу о порядке выполнения пункта седьмого Именного указа 12 декабря 1904 года в отночении девяти западньх губерний, „Право” (1905), № 1-26, s. 1575.

17 Законодательные акты переходного времени..., s. 51-53. 
Następnie można przytoczyć następującą próbę wyjaśnienia tego problemu, podaną przez jednego z gubernatorów: „Za osobę polskiego pochodzenia uważa się tego, kto urodził się z polskich rodziców i sam jest katolikiem. Przyjęcie prawosławia przez niego, lub przez jego rodziców nie zmienia jego polskiej narodowości. Tylko pochodzenie wnioskodawcy wyznającego wiarę prawosławną od rodziców urodzonych w prawosławiu, można uznać za dostateczną podstawę do uznania wnioskodawcy za osobę niepolskiego pochodzenia".

Odnosząc się ze swojej strony do rozpatrzenia niniejszej kwestii, uważam osobiście, że identyfikowanie polskiego pochodzenia z przynależnością do kościoła katolickiego chyba nie jest prawidłowe. Po pierwsze, w Kraju Zachodnim znajduje się liczna grupa ludności katolickiej, która nie tylko nie uważa siebie za Polaków, ale jest antagonistyczna wobec nich. Jest to narodowość litewsko-żmudzka zasiedlająca gubernię kowieńską, licząca w przybliżeniu około 1,5 miliona. Litwini od tego czasu, gdy wśród nich ze szczególną mocą zaczęła pojawiać się świadomość narodowa, zwłaszcza od połowy lat 80., w takim stopniu zaczęli odróżniać się od Polaków, że zaczęli domagać się wprowadzenia dla siebie nabożeństwa dodatkowego nie po polsku, a po litewsku. Na tym podłożu między Polakami a Litwinami dochodziło do krwawych starć w kościołach.

Przeciwko identyfikacji polskiego pochodzenia w oparciu o przynależność do kościoła katolickiego, przemawia i ten wzgląd, że wśród Polaków znajduje się niemało luteranów, a są nawet i prawosławni. I tak w 1902 r. ministerstwo [prawdopodobnie MSW - R.J.] w raporcie dla Senatu uznało za osobę polskiego pochodzenia jednego prawosławnego, który wniósł skargę na zaliczenie go do osób polskiego pochodzenia. Poza tym można wskazać na istnienie u nas działaczy społecznych i państwowych, których nie można nie uznać za osoby rosyjskiego pochodzenia, mimo wyznawania przez nich wiary katolickiej. Pozwolę sobie na podanie jednego przykładu. Jego nazwisko podam później. Urodził się w Wilnie, w rodzinie katolickiej i sam jest katolikiem. Kształcił się w Gimnazjum Wileńskim. Potem wyjechał do Petersburga, wstąpił do jednej z wyższych uczelni, potem do jednej z akademii. Ukończył studia i został w niej profesorem. Wykładał sztukę fortyfikacji Jego Imperatorskiej Wysokości Cesarzowi Imperatorowi. Drugą jego specjalnością była muzyka, do której posiadał olbrzymi talent, przy czym w ciągu ponad 40 lat był krytykiem muzycznym, $\mathrm{z}$ fanatyzmem bronił tak zwanej muzyki rosyjskiej, którą podziwiał i sam tworzył w duchu nowej szkoły rosyjskiej. Całe jego życie przeszło w ścisłym związku z takimi, w pełnym tego słowa znaczeniu, ludźmi rosyjskimi jak śp. W. W. Stasow ${ }^{18}$, trybun sztuki rosyjskiej, rosyjskiej przeszłości; N. A. Rimski-Korsakow ${ }^{19}$, transponujący na muzykę nasze eposy, naszą

18 Władimir Wasilewicz Stasow (1824-1906), wybitny krytyk muzyczny, historyk sztuki, archiwista, działacz społeczny.

19 Mikołaj Andriejewicz Rimski-Korsakow (1844-1908), kompozytor, dyrygent, krytyk muzyczny, twórca m.in. 15 oper, 3 symfonii. 
mitologię; Borodin ${ }^{20}$, twórca „Kniazia Igora”, Musorgskij ${ }^{21}$, Bałakiriew ${ }^{22}$. Mówię o inżynierze-generale C. A. Kjui ${ }^{23}$, którego inaczej nie można nazwać jak rosyjskim działaczem społecznym i państwowym.

Moim zdaniem narodowość polską należy określać na podstawie używania języka polskiego w życiu codziennym. Poza tym, nie odrzucając rzeczywistego związku między katolikami a polonizmem w Kraju Zachodnim, sądzę, że za Polaka należy uważać tego, kto używa języka polskiego w życiu codziennym i przy tym wyznaje wiarę katolicką. Oczywiście i tej definicji nie można uznać za w pełni wyczerpującą całą kwestię - wyjątki są oczywiście możliwe.

\section{Is every Pole a Catholic? - borderland, national and religious dilemmas of the Russian bureaucracy in a 1910 document of the Ministry of Internal Affairs}

\section{Abstract}

During the long process of introduction of zemstva (organs of local government) to the Western guberniyas of Russia (began in 1906), there was once again the problem of domination of Polish landlords within the social structures as well as political and economic life of Belarusian and Ukrainian guberniyas. The tsarist authorities, who sought to ensure the dominance of a few Russian landowners in the electoral laws to zemstva, had to set up such an electoral system that would make it possible to reduce in zemstwa the number of Polish nobility. To do so, it was necessary to determine with precision who, according to laws, was "a person of Polish origin". Prime Minister Pyotr Stolypin, preparing the introduction of national curias for the elections to Western zemstva, ordered an official of the Ministry of Internal Affairs to work out a memorial describing all the methods used after the fall of the January Uprising to distinguish Polish landowners from all the members of this class. The memorial by Alexandr Strolman, presented here in its original form and in translation to the Polish language, is a historic review of all actions taken both by local and central authorities to establish basic criteria necessary to determine and distinguish all Polish landowner from among all the landowners in Western guberniyas of Russia.

Translated by Grażyna Waluga

20 Aleksander Porfiriewicz Borodin (1833-1887), kompozytor, uczony (chemia), lekarz, skomponował m.in. operę Kniaź Igor.

${ }^{21}$ Modest Pietrowicz Musorgski (1838-1881), kompozytor, twórca m.in. oper Borys Godunow, Chowańszczyzna.

${ }^{22}$ Miłosz Aleksiejewicz Bałakiriew (1837-1910), kompozytor, pianista, dyrygent pedagog.

${ }^{23}$ Cezary Antonowicz Kjui (1835-1918), kompozytor, krytyk muzyczny, generał inżynier, wykładowca sztuki fortyfikacji. 


\section{Каждый ли католик - поляк? Кресовые, национально-религиозные дилеммы российской бюрократии в документе Министерства Внутренних Дел 1910 года}

\section{Аннотация}

Во время длинного процесса введения земств в западных губерниях России (начатого в 1906 году) в очередной раз возникла проблема доминирования польских помещиков в общественных структурах, а также в политической и экономической жизни белорусских и украинских губерний. Власти, стремясь к обеспечению преимущества немногочисленным российским землевладельцам в земской избирательной системе, должны были создать такую систему, которая позволила бы сократить в ней число польских помещиков. Чтобы сделать это, надо было сначала точно определить, кто, в свете закона, считается «лицом польского происхождения». Премьер-министр Петр Столыпин, подготавливая введение национальных курий в выборах в западные земства, поручил чиновнику Министерства внутренних дел подготовить докладную записку, объясняющую, какими методами, в период после Январского восстания, государственные власти выделяли польских помещиков из всех представителей этой социальной группы. Докладная записка Александра Строльмана, напечатанная в подлиннике и в переводе на польский, является историческим обзором действий центральной и провинциальной администраций, направленных на определение основных критериев, отличающих поляков от всех остальных землевладельцев в западных губерниях России.

Перевод Агнешка Поспишиль

\section{Bibliografia}

\section{Archiwa:}

Rosyjskie Państwowe Archiwum Historyczne w Sankt Petersburgu (Российский государственный исторический архив), f. 1284 (Департамент общих дел МВД), f. 1263 (Комитет Министров)

\section{Dokumenty:}

Полное собрание законов Российской Империи Собрание 2, т. XXXIX (1864).

Законодательные акты переходного времени. 1904-1908 гг. Сборник законов, манифестов, указов Пр. Сенату, рескриптов и положений комитета министров, относящихся $\kappa$ преобразованию государственного строя России, с приложением алфавитного предметного указателя, Изд. 3-е, пересм. и доп. по 1 сентября 1908 года, ред. Н.И. Лазаревский, Санкт-Петербург 1909.

Извлечения из Высочайше утвержденного 1 мая 1905 года особого журнала комитета министров 15, 22 и 23 марта 1905 2. по делу о порядке выполнения пункта седьмого Именного указа 12 декабря 1904 года в отношении девяти западных губерний, „Право” (1905), № 1-26. 


\section{Opracowania:}

Bazylow L., Ostatnie lata Rosji carskiej. Rządy Stołypina, Warszawa 1972.

Wieczorkiewicz P., Stołypin, Polacy i ziemstwa zachodnie, w: Słowiańszczyzna i dzieje powszechne. Studia ofiarowane Profesorowi Ludwikowi Bazylowowi w siedemdziesiąta rocznice Jego urodzin, Warszawa 1985, s. 125-153.

Базина Н.Г., Возникновение национально-политической части Департамента общих дел Министерства внутренних дел, „Известия Российского государственного педагогического университета им. А. И. Герцена” (2006), вып. № 22, т. 4, s. 17-23.

Roman Jurkowski, historyk, prof. dr hab. w Instytucie Historii i Stosunków Międzynarodowych Uniwersytetu Warmińsko-Mazurskiego w Olsztynie (kierownik Zakładu Europy Wschodniej). Jego zainteresowania naukowe skupiają się na dziejach ziemiaństwa polskiego z Ziem Zabranych ze szczególnym uwzględnieniem historii polskiej myśli politycznej na tych obszarach i działalności Polaków w życiu parlamentarnym Imperium Rosyjskiego. Autor czterech monografii: Ziemiaństwo polskie Kresów Północno-Wschodnich 1864-1904. Działalność społeczno-gospodarcza, Warszawa 2001; Sukcesy i porażki. Ziemiaństwo polskie Ziem Zabranych w wyborach do Dumy Państwowej i Rady Państwa 1906-1913, Olsztyn 2009; Successes and Failures. Polish Landowners from the Nine Western Provinces in the Elections to the Russian State Duma and State Council in the years 1906-1913, Olsztyn 2010; Kowieński marszałek, grodzieński gubernator. Kresowe początki kariery politycznej Piotra Stołypina (1889-1903), Olsztyn 2015. Wydał też drukiem obszerny zbiór dokumentów: Zanim przyszła „Pożoga”. Dokumenty i materiały dotyczace działalności polityczno-społecznej Polaków na Podolu w latach 1905-1910, Olsztyn 2011. Dorobek naukowy obejmuje ponad 140 artykułów, recenzji i publikacji materiałów źródłowych w językach polskim, rosyjskim, angielskim i litewskim (roman.jurkowski@uwm.edu.pl).

Roman Jurkowski, historian, professor dr hab., at the Institute of History and International Relations of the University of Warmia and Mazury in Olsztyn (the head of the Eastern Europe Section). His research interests focus on the history of Polish landed gentry from the so-called Stolen Lands, with special emphasis on the history of Polish political thought in those lands and activities of Poles in the parliamentary life of the Russian Empire. The author of four monographs: Ziemiaństwo polskie Kresów Pólnocno-Wschodnich 1864-1904. Działalność społecz no-gospodarcza (2001); Sukcesy i porażki. Ziemiaństwo polskie Ziem Zabranych w wyborach do Dumy Państwowej i Rady Państwa 1906-1913 (2009); Successes and Failures. Polish Landowners from the Nine Western Provinces in the Elections to the Russian State Duma and State Council in the years 1906-1913 (2010); Kowieński marszałek, grodzieński gubernator. Kresowe poczatki kariery politycznej Piotra Stolypina (1889-1903) (2015). He also has published a comprehensive collection of source texts: Zanim przyszła „Pożoga”. Dokumenty i materiały dotyczace działalności polityczno-społecznej Polaków na Podolu w latach 1905-1910 (2011). He is the author of over 140 articles, reviews, and source material publications in Polish, Russian, English and Lithuanian (roman.jurkowski@uwm.edu.pl). 